\title{
Research and Development of the Map and Assessment of Land Degradation for Sustainable Development of Land Resources (Research Location: Thua Thien Hue Province_-Vietnam)
}

\author{
Ngoc Dan Nguyen \\ Institute of Land Management \\ Northeastern University \\ Shenyang, China 110169
}

\author{
Guoping Lei \\ Institute of Land Management \\ Northeastern University \\ Shenyang, China 110169
}

\author{
Xuan Minh Tran \\ Institute of Land Management \\ Northeastern University \\ Shenyang, China 110169
}

\begin{abstract}
Land degradation research is considered as a global problem. To assess land degradation, it is necessary to assess the potential for land degradation and actual status of land degradation. Based on the global land degradation assessment (GLASOD)guidelines for the development of indicators and techniques of assessment, taking into account the specific conditions of Thua Thien Hue province, the assessment of the land degradation potential of Thua Thien Hue province has been carried out. The assessment results show that the potential for land degradation in Thua Thien Hue province is at three levels: weak, medium and strong: weak potential degradation in the study area of 103,700 ha $(20.53 \%$ of total natural area); The medium potential degradation of the study area of 208,600 ha $(41.28 \%$ of the total natural area); The strong potential degradation in the study area of 193,000 ha $(38.19 \%$ of the total natural area). The size and distribution of each level is different due to the formation of land degradation potential in different regions, which provides solutions to exploit and use land resources accordingly.
\end{abstract}

Keywords—land degradation; soil degradation potential; potential degradation map

\section{INTRODUCTION}

Land degradation leading to desertification is a global environmental issue that many countries are facing, including Vietnam. There have been many programs and actions to prevent land degradation that have been implemented in many countries around the world. The Global Land Degradation Assessment Program - GLASOD published in 1990 shows that land degradation research is a global issue. In Vietnam, land degradation research works are in three main directions: (1) soil degradation from the viewpoint of agro-forestry; (2) land degradation from the point of view of ecological environment soil pollution; (3) recognize and evaluate land degradation from a geographic point of view. From an ecological and environmental point of view, the soil is a living organism and follows the law: The development of senile degeneration, especially degradation, can occur either during the generation or metabolism phase. [1], [3], [4]. The causes of land degradation are diverse, complex and associated with the conditions of land. Land degradation is a result of current and potential degradation.

Current degradation is also known as human degradation, which occurs due to land exploitation for the benefits of human beings. Potential degradation is an indication of the level of precondition of factors involved in land degradation with a uniform assumption of vegetation cover and no human impact. Expression of potential degeneration is degenerative processes and their extent. Mapping and assessment of land degradation potential will provide the basis for a land degradation assessment based on which a system of land protection measures is proposed.

\section{THE POTENTIAL OF LAND DEGRADATION IN THUA THIEN HUE PROVINCE}

In the process of generation and development, each unit of land always has a dynamic balance (ecological balance), when the land develops to a mature level, reaching Climax, it will age and reach the stage of degradation The maturity of each land unit is manifested by the relation to the parent rock [1][3][4]. And also, weathering cover determines the nature of land during this period. Each of the landforms contains degenerate preconditions, such as: parent rock and age of parent rock, weathered crust, topography, local climatic conditions of the land [2], [4]. These factors have different degrees of degradation and different potential for land degradation. Thus, the potential for land degradation is likely to 
be the occurrence of degradation and the degree of danger of degradation process for the soil environment when the vegetation layer is destroyed. That is the basis for building criteria and assessing the potential for land degradation.

A. Criteria and Norms for Mapping and Assessment of Potential Land Degradation in Thua Thien Hue Provine

TABLE I. CRITERIA AND NORMS FOR DEVELOPING EXISTING LAND DEGRADATION MAP AT 1/100,000 SCALE

\begin{tabular}{|c|c|c|}
\hline Criteria & Index & Method of determination and calculation \\
\hline \multirow[t]{3}{*}{ 1.Terrain } & $\begin{array}{l}\text { 1.Form of } \\
\text { terrain }\end{array}$ & $\begin{array}{l}\text { Seperation and decentralization on the basis } \\
\text { of geomorphological maps }\end{array}$ \\
\hline & $\begin{array}{l}\text { 2.Terrain } \\
\text { slope }\end{array}$ & $\begin{array}{l}\text { Calculation and decentralization on the basis } \\
\text { of DEM elevation model }\end{array}$ \\
\hline & $\begin{array}{l}\text { 3.Terrain } \\
\text { elevation }\end{array}$ & $\begin{array}{l}\text { Calculation and decentralization on the basis } \\
\text { of DEM elevation model }\end{array}$ \\
\hline \multirow{3}{*}{$\begin{array}{l}\text { 2.Parent } \\
\text { rock, } \\
\text { weathering } \\
\text { cover and } \\
\text { soil }\end{array}$} & $\begin{array}{ll}4 . & \text { Parent } \\
\text { rock } & \end{array}$ & $\begin{array}{l}\text { Seperation and decentralization on the basis } \\
\text { of geomorphological maps }\end{array}$ \\
\hline & $\begin{array}{l}\text { 5. Weathering } \\
\text { cover }\end{array}$ & $\begin{array}{l}\text { Seperation and decentralization on the basis } \\
\text { of weathering cover maps }\end{array}$ \\
\hline & $\begin{array}{l}\text { 6.Thickness } \\
\text { of soil layer }\end{array}$ & $\begin{array}{l}\text { Seperation and decentralization on the basis } \\
\text { of land maps }\end{array}$ \\
\hline \multirow[t]{2}{*}{$\begin{array}{l}\text { 3.Climate } \\
\text { and } \\
\text { hydrology }\end{array}$} & 7. Drought & $\begin{array}{l}\text { Use monitoring data from } 1980 \text { to } 2010 \text { of } \\
\text { hydro-meteorological stations to calculate the } \\
\text { ratio of average monthly rainfall to potential } \\
\text { evaporation. }\end{array}$ \\
\hline & $\begin{array}{l}\text { 8. River and } \\
\text { stream } \\
\text { density index }\end{array}$ & $\begin{array}{l}\text { Separation and decentralization on the basis } \\
\text { of DEM elevation model }\end{array}$ \\
\hline $\begin{array}{l}\text { 4.Potential } \\
\text { erosision }\end{array}$ & $\begin{array}{l}\text { 9.Potential } \\
\text { level of } \\
\text { erosion }\end{array}$ & $\begin{array}{l}\text { Use Wischmeier and Smith's universal land } \\
\text { loss equations to calculate and decentralize }\end{array}$ \\
\hline
\end{tabular}

From 9 indeces selected and divided into 3 levels (weak, medium, strong), set up thematic maps for each index as shown in "Table I". Using GIS software (ArcGIS, MapInfo) allows the integration of thematic maps to create potential land $\mathrm{d}$ egradation maps.

\section{1) Form of terrain}

- (III) Hilly terrain form with steep slope, strong cleavage: strong degradation potential.

- (II) Wavy hilly terrain form with medium cleavage: medium degradation potential.

- (I) Delta terrain form, sloping, weak cleavage: weak potential degradation

2) Terrain elevation: When studying the geographic features of basaltic soil degradation in the Central Highlands, Nguyen Dinh Ky (1990) has pointed out that there is a remarkable height limit in areas with elevations above $700 \mathrm{~m}$ in potential degradation which is stronger than areas with altitudes below 700m [5]. Thus, for topographic terrain norms proposed, use and divide as in "Table II":

TABLE II. TOPOGRAPHIC ELEVATION INDECIES FOR DEVELOPING THE MAP AND ASSESSING THE POTENTIAL LAND DEGRADATION

\begin{tabular}{|l|l|l|l|}
\hline No & \multicolumn{1}{|c|}{ Terrain elevation } & \multicolumn{1}{|c|}{ Symbol } & $\begin{array}{c}\text { Level of potential } \\
\text { degradation }\end{array}$ \\
\hline 1 & Elevation $>1.000 \mathrm{~m}$ & III & Strong \\
\hline 2 & Elevation $500-1.000 \mathrm{~m}$ & II & Medium \\
\hline 3 & Elevation $<500 \mathrm{~m}$ & I & Weak \\
\hline
\end{tabular}

3) Parent rock/sample: The composition and chemical properties of the parent rock strongly affect soil properties. In Thua Thien Hue province, there are typically parent rocks such as granite, sandstone, mica, sloping sediment [6]. Depending on the type of rocks that distinguishes the type of risk, intensity of degradation as shown in "Table III".

TABLE III. TYPE OF RISK AND INTENSITY OF DEGRADATION OF PARENT ROCK / SAMPLE

\begin{tabular}{|l|l|l|l|l|}
\hline No & \multicolumn{1}{|c|}{$\begin{array}{c}\text { Parent } \\
\text { rock/sample }\end{array}$} & Risk of degradation & Symbol & $\begin{array}{l}\text { Intensity of } \\
\text { degradation }\end{array}$ \\
\hline 1 & Sandstone & Erosion, landslide & III & Strong \\
\hline 2 & $\begin{array}{l}\text { Mica slate, } \\
\text { shale }\end{array}$ & $\begin{array}{l}\text { Erosion, landslide, } \\
\text { wash away }\end{array}$ & II & Medium \\
\hline 4 & Granite rocks & Erosion, wash away & II & Medium \\
\hline 5 & $\begin{array}{l}\text { Basalt rocks } \\
\text { condenser }\end{array}$ & Erosion, wash away & II & Medium \\
\hline
\end{tabular}

4) Weathering cover: Corresponding to the above mentioned parent rocks are the following weathered covers:

- (III) Alit and Feralit weathering cover, thin to medium Sialit: Strong degradation potential.

- (II) Feralit, Sialit weathering cover, medium to thick: Medium degradation potential.

- (I) Feralit- Sialit weathering cover - thick: weak degradation potential.

5) Terrain slope:

- (III) Common slope> 250: Strong degradation potential.

- (II) Common slope 8 - 250: Medium degradation potential.

- (I) Common slope 0 - <80: weak degradation potential.

6) Soil thickness.

- (III) Layer thickness $>50 \mathrm{~cm}$ : Strong degradation potential.

- (II) Layer thickness 50 - $100 \mathrm{~cm}$ : Medium degradation potential.

- (I) Layer thickness $>100 \mathrm{~cm}$ : weak degradation potential.

7) Extremes of climate: Extreme climate variability manifests itself in many aspects in that the length and intensity of the dry season [7] posing a high risk to soil degradation ass shown in "Table IV" (Dry season is those with less than 25 $\mathrm{mm}$ rainfall and dry season intensity is calculated by the appearance of drought months with less than $25 \mathrm{~mm}$ of rainfall). 
TABLE IV.

EXTREMES OF CLIMATE FOR DEVELOPING THE MAP AND ASSESSING LAND DEGRADATION

\begin{tabular}{|c|c|c|c|}
\hline No & Extreme of the climate & Symbol & $\begin{array}{l}\text { Level of potential } \\
\text { degradation }\end{array}$ \\
\hline 1 & $\begin{array}{l}\text { Dry center (where the dry season } \\
\geq 4 \text { months, the number of dry } \\
\text { months } \geq 3 \text { months) }\end{array}$ & III & Strong \\
\hline 2 & $\begin{array}{l}\text { The area has an average dry } \\
\text { season (where there are 3-4 dry } \\
\text { months, } 2-3 \text { drought months) }\end{array}$ & II & Medium \\
\hline 3 & $\begin{array}{l}\text { The area has a short dry season } \\
\text { (where there are } \leq 2 \text { dry months) }\end{array}$ & I & Weak \\
\hline
\end{tabular}

8) River and stream density index: When the research of development of potential land degradation map of Bhutan, Moe Myint and Pema Thinley (2006) suggested that river and stream density is an important factor for land degradation through the process of erosion, washing away. The authors have assessed and divided six levels of potential degradation with the density of rivers and streams [8]. For the potential land degradation assessment in this study, the researchers have grouped and divided into 3 levels as in "Table V":

TABLE V. RIVER AND STREAM DENSITY INDEX FOR POTENTIAL LAND DEGRADATION ASSESSMENT

\begin{tabular}{|l|l|l|l|}
\hline No & $\begin{array}{c}\text { River and stream } \\
\text { density }\left(\mathbf{k m} / \mathbf{k m}^{\mathbf{2}}\right)\end{array}$ & \multicolumn{1}{|c|}{ Symbol } & $\begin{array}{c}\text { Level of potential } \\
\text { degradation }\end{array}$ \\
\hline 1 & $<0,5$ & I & Weak \\
\hline 2 & $0,5-1,0$ & II & Medium \\
\hline 3 & $>1,0$ & III & Strong \\
\hline
\end{tabular}

9) Potential erosion criteria

The level of potential erosion is used to assess the potential land degradation in Thua Thien Hue. On the potential soil erosion map, the scale of $1 / 100,000$, the study area is divided into 4 levels as in "Table VI":
TABLE VI. DECENTRALIZATION OF Potential SoIl ERosion CRitiera FOR POTENTIAL DEGRADATION ASSESSMENT

\begin{tabular}{|l|l|l|l|}
\hline No & $\begin{array}{c}\text { level of potential erosion } \\
\text { (ton/ha/year) }\end{array}$ & Symbol & \multicolumn{1}{|c|}{$\begin{array}{c}\text { Level of potential } \\
\text { degradation }\end{array}$} \\
\hline 1 & $<100$ & I & Weak \\
\hline 2 & $100-500$ & II & Medium \\
\hline 3 & $500-1.000$ & III & Strong \\
\hline
\end{tabular}

B. Procedure for Assessment of Land Degradation Potential in Thua Thien Hue Province

Based on GLASOD guidelines on the development of indicators and evaluation techniques taking into account the specific conditions of Thua Thien Hue province, development of a map and assessment of the potential for land degradation in Thua Thien Hue province are conducted according to the following process:

- Step 1: Make collection and standardization of the baseline map of the study area as "Fig. 1".

- Step 2: Make collection of vegetation cover maps, geological maps, weathering cover Atlas, topographic maps, geomorphological maps, land maps, hydrometeorological data, potential erosion maps, soil thickness maps, Drought index maps, river and stream density maps, remote sensing image databases, field surveys, additional soil samples.

- Step 3: Compile component maps with a scale of 1: 100,000

- Step 4: Composite component maps with GIS technology, make synthesis of component maps based on consultation from experts.

- Step 5: From the overlap results, assess the type of land degradation, scale of each type of degradation. In particular, types of land degradation are the synthesis of levels of degeneration associated with the size of the area. 


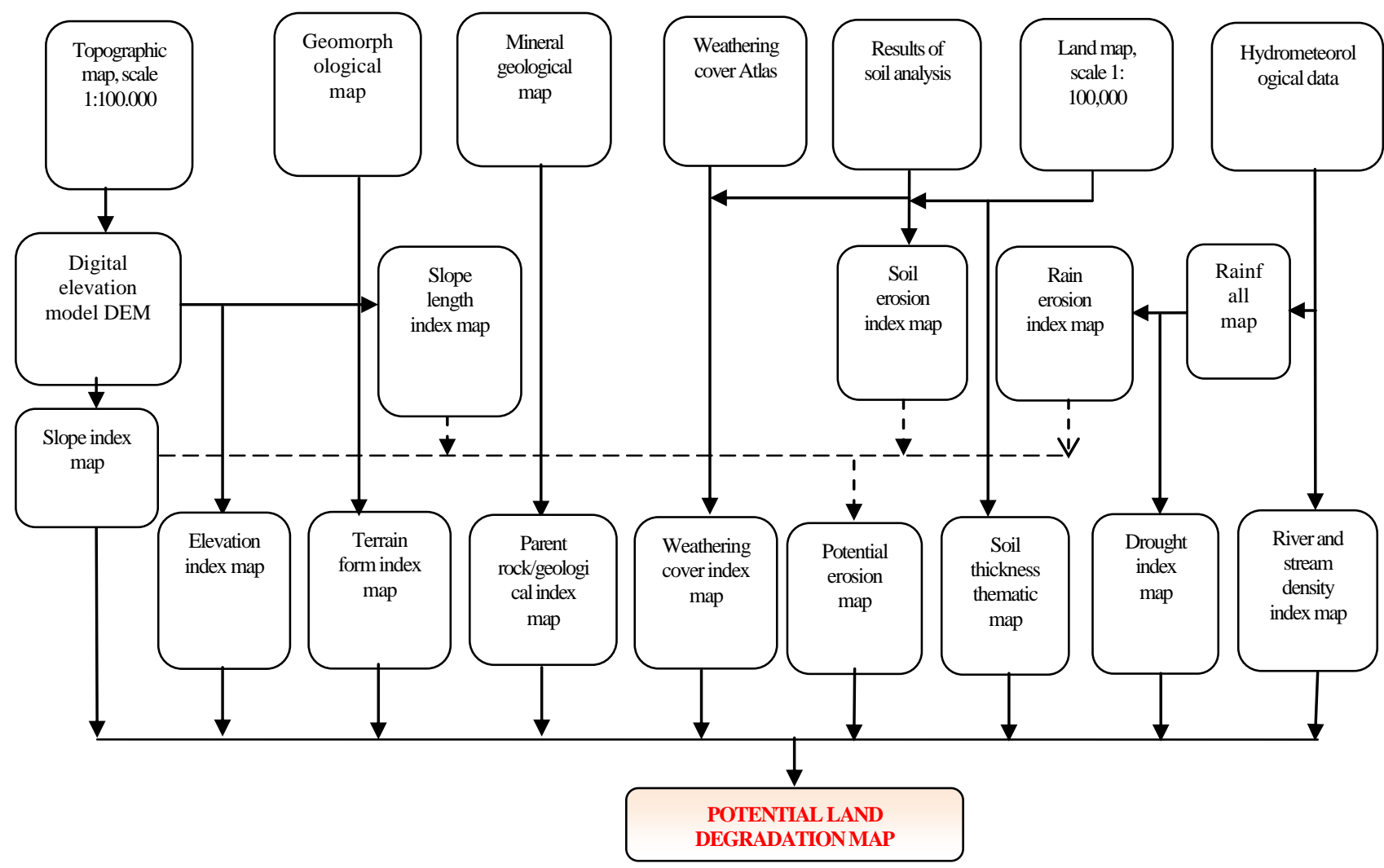

Fig. 1. Diagram of potential degradation mapping process in Thua Thien Hue Province.

\section{Results of Mapping and Assessment of Potential Land Degradation in Thua Thien Hue Province}

Combining these elements by correlation matrix and make aggregation through element maps allows assessing the risk of land degradation in Thua Thien Hue. The potential for land degradation in the study area is divided into three levels: weak degradation potential; Medium degradation potential; strong degradation potential.

Each level has different expression features of the region and dominant degeneracy processes as in "Table VII".

TABLE VII. Characteristics of LeVEls of Risk of Degradation IN Thua ThiEN Hue Province

\begin{tabular}{|c|c|c|}
\hline Level of degradation & Natural characteristics of the occurrence area & Degradation process \\
\hline Weak & $\begin{array}{l}\text { - The valley mudflats are narrow. } \\
\text { - Terrain is flat, narrow mudflats, accumulate or slightly inclined towards } \\
\text { the river bed, sometimes slightly wavy. } \\
\text { - Typical slope } 0 \text { - }<80 \text { - Feralit - Sialit weathering layer, thick depositing. } \\
\text { - The dry season is short }\end{array}$ & $\begin{array}{l}\text { - Wash away surface, weak de-colouring } \\
\text { - Acupuncture and horizontal accretion. } \\
\text { - Flooding, salinization. }\end{array}$ \\
\hline Medium & $\begin{array}{l}\text { - Soil eroded, driftwood, elevation less than } 700 \mathrm{~m} \text {. } \\
\text { - The terrain is wavy hills, slope } 8-250 \\
\text { - Feralit, Sialit weathering layer, medium to thick } \\
\text { - Dry season is not harsh, heavy rain but not concentrated }\end{array}$ & $\begin{array}{l}\text { - Wash away surfaces on the slopes, accumulate deluvi - } \\
\text { proluvi in the hollow areas, slopes. } \\
\text { - Deep medium eradication } \\
\text { - Laterit formed in the block } \\
\text { - Average synthetic abrasion on slopes } 8-250\end{array}$ \\
\hline Strong & $\begin{array}{l}\text { - Soil on the top surface of the dome or skylight, on the terrain denuded on } \\
\text { limestone and other rocks, with the elevation of over } 700 \mathrm{~m} \text {. } \\
\text { - Strong erosion, wash away }\end{array}$ & $\begin{array}{l}\text { - Strong synthetic abrasion. } \\
\text { - Slides and landslides on very sloping and steep slopes. } \\
\text { - Flush drift and landslide on limestone }\end{array}$ \\
\hline
\end{tabular}

The results of the potential land degradation assessment in the study area of $1 / 100,000$ scale based on the above criteria are as follows:

1) Weak degradation potential: The area of low degradation potential in the study area is 103,700ha ( $20.53 \%$ of the total natural area of the region). It is the most distributed in Phu Loc District $(39,450)$, followed by Phong Dien (38,870ha), Huong Tra District (32,230ha),
Huong Thuy district (21,960ha), Quang Dien district (19,120 ha), A Luoi district (16,120 ha) ha), Nam Dong district (10,750 ha), Hue City (2,547 ha) as in "Fig. 2". 


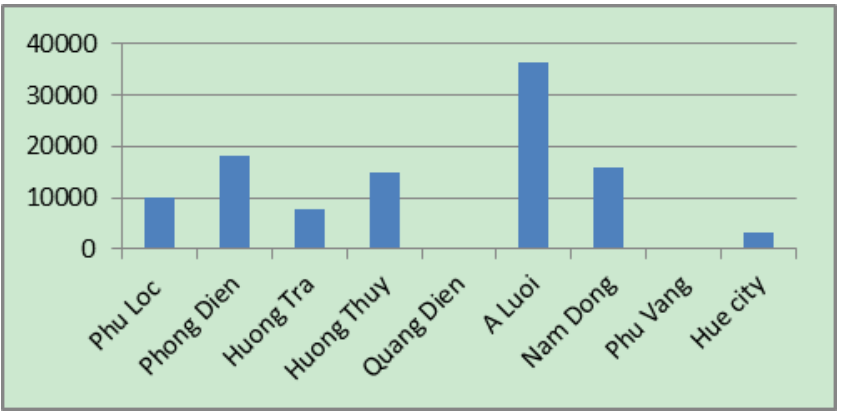

Fig. 2. Area of low soil degradation potential of the districts in the study area (ha).

The potential land degradation map in scale of $1 / 100,000$ of the study area shows that the low degradation potential arear is mainly located on the thick feralit - Sialit deposition and alluvial, accumulation slope with thickkness of usually> $100 \mathrm{~cm}$, flat terrain, and average height below $500 \mathrm{~m}$. These areas are being used for long-term industrial crops and also for maintaining natural forest vegetation.

2) Medium degradation potential: Total medium degradation potential area of the study area is 20,600 ha (accounting for $41,28 \%$ of the total natural area of the study area). They are mostly distributed in A Luoi District (36,380 ha), followed by Phong Dien district (18,190 ha), Nam Dong district (15,930 ha), Huong Tra district (14,900 ha), Phu Loc district (9,974 ha), Hue City (3,246 ha) as in "Fig. 3".

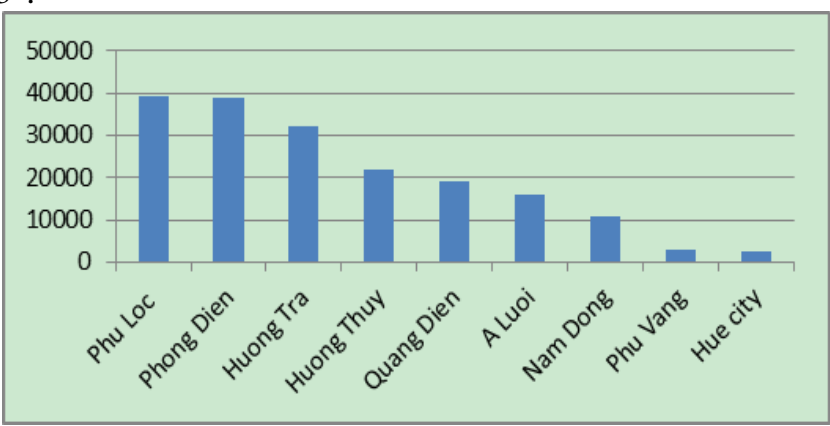

Fig. 3. Area of medium degradation potential soil of districts in study area (ha).

The mapping units with medium degradation potential are the types of soils produced on mica shale, clay shale, granite, basaltic rock, weathered feralit, Silty layers, with size from medium to thick, thickness from 50 to less than $<100 \mathrm{~cm}$, in the terrain with average slope of less than 150 or located in areas with a dry season of less than 4 months and drought months of less than 2 months. "Fig. 3"

3) Strong degradation potential: Area of high degradation potential soil in the study area is 193,000 ha (accounting for $38.19 \%$ of total natural area of the area). They are most located in A Luoi district (70,320 ha), Phong Dien district (38,320 ha), Nam Dong district (37,920 ha), Phu Loc district (23,000 ha), Huong Thuy district (15,980 ha) Hue City (7,121 ha), Huong Tra district $(4,829)$, Quang Dien district (2,172 ha) as in "Fig. 4".

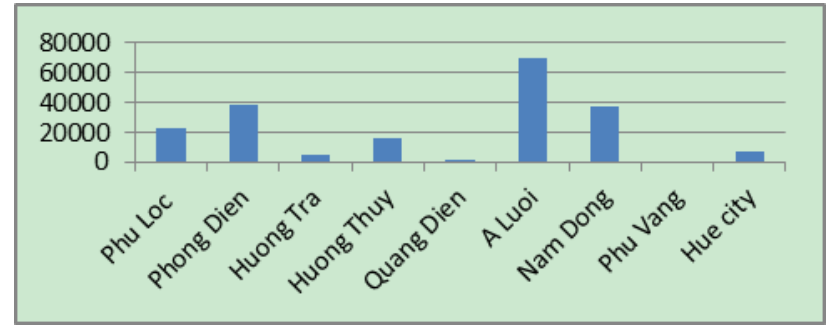

Fig. 4. Area of high degradation potential soil of districts in study area (ha).

The map in "Fig. 5" shows that the strong degeneration potential unit are soils with a thickness of $30-50 \mathrm{~cm}$, growing on sandstone with risk of sliding and erosion or in areas with dry season lengths of more than 4 months, months and drought time of less than 3 months as in "Table VIII".

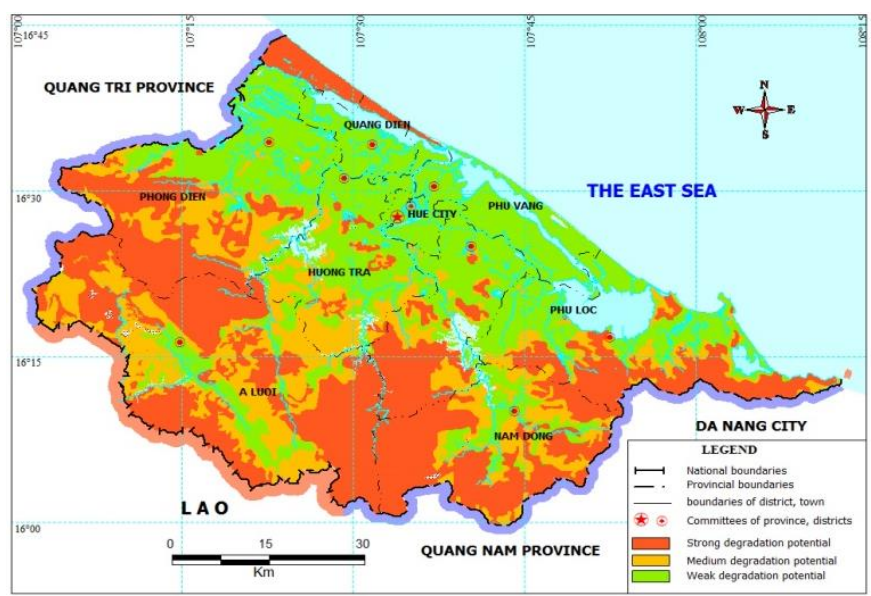

Fig. 5. Map of degradation potential of Thua Thien Hue province.

The results in "Table IX" show that the potential for land degradation in Thua Thien Hue province has all three levels: low, medium and high. The scope of each level is different from the other due to the formation conditions of land degradation potential in different regions. 
TABLE VIII. LENGND

\begin{tabular}{|c|c|c|c|c|c|c|}
\hline Code & $\begin{array}{c}\text { Level of } \\
\text { degradation }\end{array}$ & Characteristics of degradation & Degenerative processes & Type of soil & Area (ha) & Ratio (\%) \\
\hline & Strong & $\begin{array}{l}\text { - Slope, very steep topography > } \\
250 \\
\text { - Strong erosion, washout } \\
\text { - Thin to medium weathered shell } \\
\text { - Unstable sand dunes, sand } \\
\text { beaches } \\
\text { - Low-lying terrain, flooded } \\
\text { regularly }\end{array}$ & $\begin{array}{l}\text { - Strong abrasion, groove } \\
\text { erosion } \\
\text { - Sliding and falling on steep } \\
\text { slopes } \\
\text { - Strongly eroded skeletal } \\
\text { soils } \\
\text { - Backfill, sand fly, sand } \\
\text { flow, inundation, salt glay }\end{array}$ & $\begin{array}{l}\mathrm{Ha}, \quad \mathrm{Hj}, \\
\mathrm{Fs}, \mathrm{Fq} \ldots \\
\text { C, Cc, D, E, } \\
\text { J, } \\
\text { M, Mn }\end{array}$ & 193.000 & 38,19 \\
\hline & Medium & $\begin{array}{l}\text { - The terrain is wavy mountains, } \\
\text { sloping from } 15 \text { - } 25 \text { degrees } \\
\text { - Lateritic, feralit, medium to thick } \\
\text { weathered shells }\end{array}$ & $\begin{array}{l}\text { - washout on the surface of } \\
\text { laterite slabs, forming } \\
\text { aggregates, beeswax, } \\
\text { degraded and salinized soil } \\
\text { - Average synthetic abrasion } \\
\text { of slopes with a slope of } 15 \text { - } \\
250\end{array}$ & $\mathrm{Ha}, \mathrm{Hj}, \mathrm{Fa}, \mathrm{Fs}$ & 208.600 & 41,28 \\
\hline & Weak & $\begin{array}{l}\text { - Flat land, narrow mudflats, } \\
\text { accumulated or scattered soil, } \\
\text { sometimes wavy } \\
\text { - common slope from } 0-<150 \\
\text { - thick accumulated weathering } \\
\text { shell }\end{array}$ & $\begin{array}{l}\text { - weak washout, exhausted } \\
\text { soil } \\
\text { - horizontal } \\
\text { sedimentation, } \\
\text { glaying }\end{array}$ & $\begin{array}{l}\mathrm{Ha}, \mathrm{Fa}, \mathrm{Fs}, \mathrm{P}, \\
\mathrm{Pb}, \mathrm{Pf}\end{array}$ & 103.700 & 20,05 \\
\hline \multicolumn{5}{|c|}{ Total area } & 503.300 & 100 \\
\hline
\end{tabular}

a. Note: Ha, Hj (Humic Acrisols), Fs (Ferralic Acrisols), Fq (Haplic Acrisols), C (Haplic Arenosols), Cc (Luvic Arenosols), D (Gleysols), E (Leptosols), J (Umbric Gleysols), M (Solonchaks), Mn (Haplic Solonchaks), Fa (Ferralic Acrisols), P (Dystric Fluvisols), Pb (Dystric Fluvisols), Pf (Plinthic Fluvisols).

TABLE IX. POTENTIAL FOR LAND DEGRADATION LEVEL IN THUA THIEN HUE PROVINCE

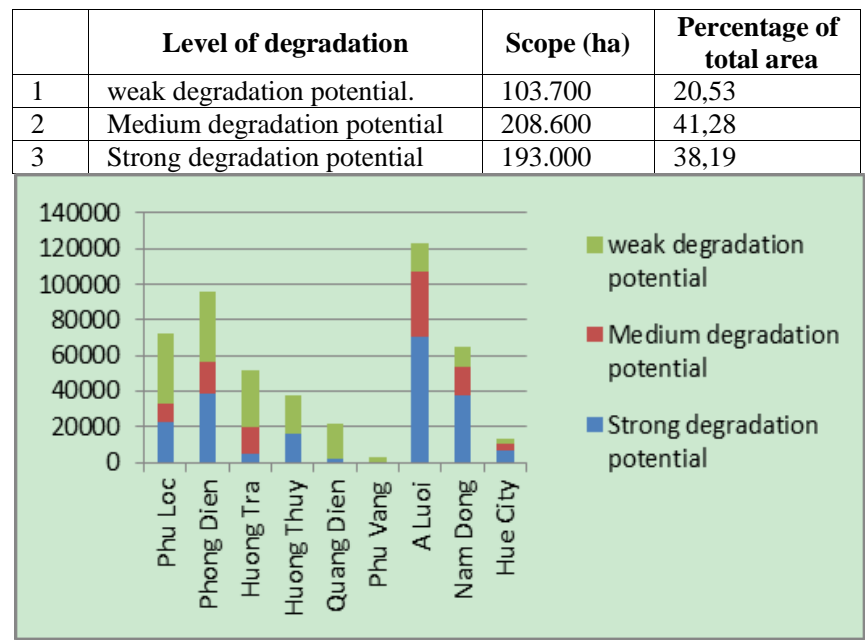

Fig. 6. Scale of potential land degradation levels by districts in study area (ha).

Most of the land in Thua Thien Hue Province has high and medium potential level of land degradation, both levels account for $80.47 \%$ of the province land area. "Fig. 6" The specific distribution area of land degradation potential levels in the province is as in "Table $\mathrm{X}^{\text {": }}$
TABLE X. AREA SUMmary OF DEGRADATION Potential LEVELS IN STUDY AREA BY ADMINISTRATIVE UNIT

\begin{tabular}{|l|l|l|l|l|}
\hline $\begin{array}{l}\text { Degradation } \\
\text { Districts }\end{array}$ & D1 & D2 & D3 & $\begin{array}{l}\text { Total } \\
\text { (ha) }\end{array}$ \\
\hline A Luoi & 16.120 & 36.380 & 70.320 & 122.820 \\
\hline Nam Dong & 10.750 & 15.930 & 37.920 & 64.600 \\
\hline Phong Dien & 38.870 & 18.190 & 38.320 & 95.380 \\
\hline Quang Dien & 19.120 & & 2.172 & 21.292 \\
\hline Phu Vang & 2.800 & & & 2.800 \\
\hline Huong Tra & 32.230 & 14.900 & 4.829 & 51.959 \\
\hline Huong Thuy & 21.960 & 7.700 & 15.980 & 45.710 \\
\hline Hue city & 2.547 & 3.246 & 7.121 & 12.914 \\
\hline Phu Loc & 39.450 & 9.974 & 23.000 & 72.424 \\
\hline Total (ha) & 103.700 & 208.600 & 193.000 & 505.300 \\
\hline Ratio(\%) & 20,53 & 41,28 & 38,19 & 100 \\
\hline
\end{tabular}

The largest area of high degradation potential-land is located in A Luoi district (twice as much as in Nam Dong and Phong Dien districts and several times higher than in other districts), followed by Nam Dong and Phong Dien districts. We have not seen any land area with medium and high degradation potential level in Phu Vang district. There is not much land with high degradation potential in Quang Dien district.

\section{CONCLUSION}

Due to the forming characteristics, the recovery and utilization of potential degradation levels in Thua Thien Hue province are different.

- For areas with high degeneration potential level, which is distributed in Nam Dong, A Luoi and Phu Loc districts, land degradation is mainly caused by landslide processes on steep slopes, with high slope and altitude, therefore it is difficult to recover. These 
areas need to use some measures such as strictly protecting watersheds, prohibiting deforestation, increase protection forest area.

- For areas with medium potential degeneration level, which are located in Phong Dien, Quang Dien, Nam Dong and Phu Loc districts, the potential for degradation is mainly caused by surface washout on the slopes and Deluvi-proluvium accumulation in lowland areas, mountain bases, therefore they can be restored by combined agroforestry measures using specific RVAC model (Forest - garden - fishpond livestock pen), VAC.

- For areas with low potential for land degradation, located in Phu Loc, Quang Dien and Phu Vang districts, which mainly occurs in the eastern coastal plains with flat terrain, accumulated on alluvial soil, gley soil and gley gray soil, the potential for soil degradation here is mainly weak washout, alluvion, inundation and gleying .... so the recovery can be achieved if the agroforestry measures are applied, such as growing food crops, cash crops and coastal protection forests

\section{REFERENCES}

[1] Le Huy Ba, Environment of Land Resources in Vietnam, Vietnam Education Publishing House, 2009

[2] Global Assessment of Soil Degradation GLASOD, Soil Degradation status map by human activities, ISRIC, 1990.

[3] Nguyen Anh Hoanh, General Research on Arising Geography of Land Degradation for Rational Use of Land Resources and Natural Disaster Prevention in Binh Tri - Thien Area, PhD thesis, Hanoi, 2010.

[4] Nguyen Dinh Ky et al., Study on criteria for land degradation assessment for potential degradation mapping in Quang Binh - Quang Tri - Thua Thien Hue province, Summary report of Vietnam Institute of Science and Technology-level thesis, Hanoi, 2005.

[5] Nguyen Dinh Ky (1990). Arising geographical features and soil degeneration on the tropical basaltic plateaus (for example, the Central Highlands of Vietnam). PhD thesis on geography, Soviet Academy of Sciences, Moscow

[6] Nguyen Van Trang et al, Geology and minerals Huong Hoa - Hue Da Nang 1: 200,000, Hanoi, 1996.

[7] Department of Science and Technology of Thua Thien Hue Province. Thua Thien Hue's climate and hydrographical characteristics. Thuan Hoa Publishing House, 2004

[8] Smyth A.J. and Dumanski J. (1993). FESLM: An international framework for evaluating sustainable land management. A discussion paper, FAO, Rome, Italy.

[9] Nguyen Dinh Ky et al., Assessment and Forecast of Land Degradation in the North

[10] Oldeman, L.R; Hakkeling, R.T.A; Sombroek, W.G, World map of the status of human - induced Soil Degradation; an explanatory notes, Global Assessment of Soil Degradation GLASOD, 1991.

[11] Smyth A.J. and Dumanski J. (1993). FESLM: An international framework for evaluating sustainable land management. A discussion paper, FAO, Rome, Italy. 